\title{
Influence of the Turkish Empire on Malaya in the Malay Manuscript of the Leiden University Library Collection
}

\author{
Muhammad, S.J.N ${ }^{*}$, Rahman, N.S.A ${ }^{2}$, NRNM Affendi ${ }^{3}$, A Asmiaty ${ }^{4}$ \\ ${ }^{1,3}$ Universiti Putra Malaysia, Malaysia \\ ${ }^{2}$ Universiti Utara Malaysia, Malaysia \\ ${ }^{3}$ Universiti Malaysia Sabah, Malaysia \\ *salmahjan@upm.edu.my
}

\begin{abstract}
When researching the catalogues about Malay manuscripts at the library of Leiden University, Netherlands, there was a list of records about Turkey and Malaya's relations in various manuscript collections in the library. This is important to be highlight to see how far the two empires' relationship are in Malay manuscripts. Thus, this writing will analyze the Turkish Empire's influence towards the Malay government in various aspects. The analyze will using the selected Malay manuscripts through the Leiden University Library collection. Qualitative content analysis methods will use to examine the topics. The expectation of writing shows that there are significant influences towards the Malay government, especially about lineage and politics. This writing will directly contribute to the studies on international relations between the Turkish Empire and Malay government and highlight the way the government practiced by the Islamic government in maintaining the relationship as stated in the Malay manuscript.
\end{abstract}

Keywords

Influence; Leiden University; Malaya; Malay Manuscript;

\section{Introduction}

Hikayat Muhammad Hanafíyah. These manuscripts feature a narrative related to the Turkish society and region. These three manuscripts were generally included as the earliest manuscripts from traditional Malay Islamic literature category. This is which replace epics of Hinduism and has been translated and adapted into the Malay Language in the 14th century in Samudera Pasai's Kingdom that belongs from Islamic tradition of Persia and India (Iskandar, 1995). These manuscripts cover the field of knowledge, the field of Islam, literature, law, medical, employment, history, society, technology, language and writing etc. (Musa, H., Rodi, R.C., Pondo, H., Muhammad, S.J.N, 2013).

A well-organized government, a strong economy, a society that adheres to the Islamic value and has a strong military has elevated the Turkish Empire as an idol amongst the kingdom especially the Islamic kingdom in the archipelago. There were several graduate studies done about the relationship between Turkish and Malaya, such as, Abdul Jalil Borham (2011), Ermy Azziaty (2014), Mat Rofa Ismail (2015) that discuss Turkey's greatness in the eyes of Malayan rulers. Thus, there is a question, what are the influences of Turkish Empire can be traced in Malay kingdom based on the event recorded in the Malay manuscript especially the manuscripts stored in the collections of Leiden University Library, Netherlands? Therefore, to answer the question given, this writing will identify and analyse Turkish Empire's influences towards Malay kingdom in the chosen manuscripts as an research purpose. In this study, the discussion will be restricted into a few of the Malay Sultanate such as Kedah, Acheh and Johore. The Hikayat Merong Mahawangsa, Hikayat Negeri Johor, Syair Sultan Abu Bakar (this manuscript was used as an additional manuscript which is the continuity of Hikayat Negeri Johor), Hikayat Aceh and Bustan al-Salatin as the primary research material in the discussion to identify the topic of discussion.

a) Hikayat Merong Mahawangsa in the Leiden University Library collection numbered Or. $26.739: 12$ is a collection of Prof. Dr. Johannes Jacobus Ras (19262003). 
b) Hikayat Negeri Johor @ Hikayat Johor in the Leiden University Library collection numbered Or. 1741: 2.

c) Hikayat Aceh in the Leiden University Library collection numbered Or. 1954

d) Bustan al-Salatin in the Leiden University Library collection numbered Or. 1694, Or. 1973, Or. 1974.

This study uses the library method to obtain research data by referring to primary and secondary sources such as books, theses, articles published in journals. There are four planned study procedures selecting, collecting, analyzing and formulating data. At the data collection stage, the author researches selected manuscripts that are appropriate to the study's objectives. Each reading of the manuscript's contents was researched and recorded, especially the information that discusses the topic of the study. At the data analysis level, the focus is on the information obtained from the first level while at the third level, the information obtained will be analysed to facilitate the analysis process. The fourth level is to make an overall conclusion on the topic of discussion.

\section{Discussion}

This section will highlight some of the findings found such as the discussion shown below;

\section{Lineage}

By nature, lineage is significant to ensure that the lineage has a good quality heritage and credibility, especially when it involves the ruling class in a government. This is because, the ruling class must have the intelligence to think and resilience in determining their rule's direction. Therefore, lineage must be well preserved. When examining the old manuscripts, especially those in the historiographic genre, there will be a royal marriage that involved the great kingdoms, such as the kingdom of Melaka with the kingdoms of China and Majapahit. In the other hand, there are also events associated with fantastical elements for the greatness of a generation. Siti Hawa Salleh (1998) considers that, despite having a mythical element, the story of origin or lineage is very fundamental and has a historical value. This is to ensure that the descendants of a kingdom will be great.

Kedah was a kingdom or a government that adapt to the Turkish Ottoman elements by inspiring them into their writing. One of the famous historiography manuscripts of the Malay Sultanate of Kedah is Hikayat Merong Mahawangsa. Hikayat Merong Mahawangsa is the most important Malay masterpiece that narrated the history of origin Kedah and Kedah Sultanate's lineage. Although neither the author nor the date of writing was unknown, this text is the literary results that showed the way of an old Malay community thinking about a history writing in their way (Harun, 2000). Hikayat Merong Mahawangsa has recorded that the King of Kedah's lineage came from a nobleman descended from the Roman Kin named Merong Mahawangsa. Although, there is a discussion said that Merong Mahawangsa's origin was from India such as G. Mohamed Khan (1958) and Dzulkifli Salleh (1965) were not discuss this matter.

According to Jacob M. Landau (1990), the Malay Peninsula community and the Dutch East India considers 'King of Rome' as a great and powerful king. Since the 16th century, this title was given to the Ottoman Turkish Sultanate as a great Islamic government and their role as supporters of the Islamic caliphate. Therefore, the relation between the lineage of Kedah and Rome (Turkey) was significant to increase the greatness of their heirs of the Kedah government.

The lineage of Kedah and Rome (Turkey) in Hikayat Merong Mahawangsa can be see through the passage below:

The story begins, the King of Rome is meeting with the great kings. They are crowned, with all the ministers and officials, chief of soldiers, officers in the palace, heralds, royal servant, crowded the hall of paseban agung, meeting to talk to deliver his son to Continent China and brought all the equipment of ships and ships looking for hope to replace him. So in many of 
the kings who sat facing it was a great king with a crown, a friend to him, named Raja Merong Mahawangsa.

(Sebermula, maka tersebutlah perkataan Raja Rom sedang dihadapi segala raja-raja besar yang bermakuta, dengan segala menteri dan para penggawa,hulualang, sida-sida, bentara, biduanda sekalian, penuh sesak balai paseban agung, bermesyuarat bicara hendak mengantarkan anakanda baginda ke-Benua China serta menghadirkan segala kelengkapan bahtera dan kapal mencari harapan akan ganti baginda itu. Maka dalam banyak segala raja-raja yang duduk mengadap itu adalah seorang raja yang besar lagi bermakuta, sahabat kepadanya, bernama Raja Merong Mahawangsa.)

The lineage between Kedah and Turkey is seen as something that brings goodness and glory to the Kedah government. Raja Merong Mahawangsa such as Raja Merong Mahapudisat, Raja Seri Maha Wangsa, Raja Seri Maha Indera Wangsa, and Raja Phra Ong Maha Wangsa who later became known as Sultan Muzaffar Syah after embracing Islam have led to the glory of Kedah. Kedah Government developed between 5-13 century AD. It was the oldest harbour and the oldest government on the west coast of the Malay Peninsula. The success relationship of consanguinity with the legacy of the Roman empire (Turkey) is the proof. Hendrik M.J. Maier (1988) says that Orc connects the Kedah royal family to Rome and Byzantium was to give the perception of the creation of a Malay kingdom in touch with other governments.

Besides Hikayat Merong Mahawangsa, there is others manuscript called Sejarah Melayu that relates and records the lineage with the Turkish government. When the heirs of the Sultan of Malacca Sultanate highlight Raja Arashtun Shah, the son of Sultan Iskandar Zulkarnain from Macedonia married the princess of Turkistan. Siti Hawa Salleh (1998) says that, this event is manifested in the Hikayat Merong Mahawangsa and related to Macedonia and Rome located in the same district in West Asia. Usually, the ruling class descended their descendants and associated with the famous king to strengthen the ruling Sultan's right. The Sultan's position is further strengthened by sovereignty, customs, customs of greatness and privileges (Mohammad Isa Othman, 1990). Hikayat Merong Mahawangsa was also studied by Nurul Izzah Mohd Johari, et.al (2020)

\section{Royal Diplomatic Visits}

Diplomatic relations are very important to build and strengthen a government's civilisation. Diplomacy is the relationship between two or more governments with common goals and interests. When these governments' mission and vision are parallel, then diplomatic relations are easily established. In this case, the diplomatic relations is not just fulfilling interests. Still, the government also must act by focusing on the methods of forming, organizing and controlling diplomatic relations carefully so that the relationship is not easily disturbed by external threats (Salmah Jan Noor Muhammad, 2017). Various diplomatic relations can be established including, political, social, religious diplomacy and, etc. There are events in the manuscript that had diplomatic ties between Turkey and the Malay kingdoms.

In Hikayat Negeri Johor and Syair Sultan Abu Bakar, Sultan Abu Bakar has recorded the royal visit to Turkey. Hikayat Negeri Johor as a source of modern history written by Mohd. Said bin $\mathrm{Hj}$. Sulaiman is the secretary to the late Sultan Ibrahim (1895-1959) while Mohd Yusof Md studied Syair Sultan Abu Bakar. Both of these manuscripts are very important in recording the development of the sultan's rule in Johore. Among the studiers who studied the state of Johor is Abdullah, A. R. (2013) and A. Milner (2014).

Sultan Abu Bakar often made royal visits to foreign governments, especially influential governments, to strengthen his rule. According to 
Mohd Said Sulaiman (1930), Sultan Abu Bakar (1862-1895) was the responsible king towards his government's foreign policy by holding various diplomatic visits with European and Middle Eastern countries.

Meanwhile, Buyong Adil (1980) said that Sultan Abu Bakar and his son, Sultan Ibrahim, often visited abroad to establish ties with other countries, including the Ottoman government. Sultan Abu Bakar made his royal visit to the government in 1866, 1879 and 1893. Through this event it was also noted that the Johore government is the only government that is serious about making Islam the pillar of the government. This has opened the diplomatic space of Johor and Turkey in establishing relations on the importance of maintaining Islamic teachings.

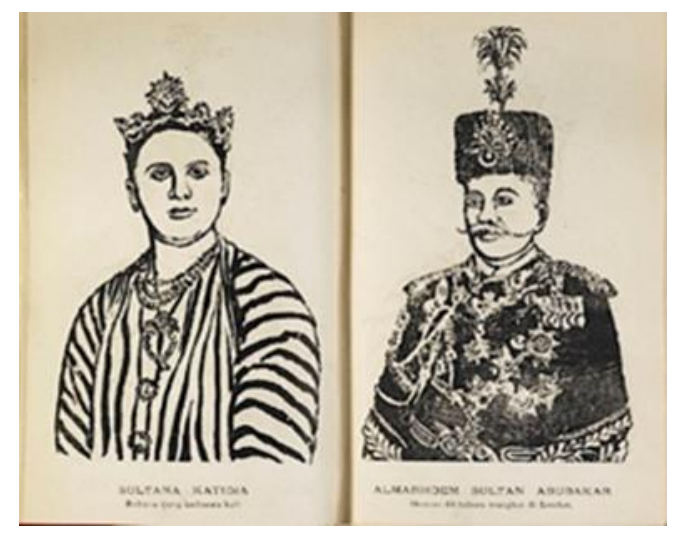

Figure 1. Sultan Abu Bakar from Johore - the first Malay King visit Turkey and his Turkish wife, Sultana Khadijah. Na Tien Piet, Shaer Almarhoem Beginda Sultan Abubakar di Negri Johor (Singapore, 1896). Source: British Library 14626.a.6

The Royal Visit of Johore to Turkey in Hikayat Negeri Johor was recorded as follows:

Until finally, His Majesty (Sultan of Johore) met with His Majesty Sultan Abdul Hamid Khan in Constantinople (Istanbul). So he was well received by the king and well celebrated because he was very fond as His Majesty the Sultan of Turkey saw a king in the east is so good and rules in matters of Islam.
(Hingga pada akhirnya lantaslah Yang Maha Mulia (Sultan Johor) berjumpa dengan Yang Maha Mulia Sultan Abdul Hamid Khan di Konstantinopel (Istanbul). Maka diterimalah oleh baginda dengan sebaik-baik terimaan serta diraikan dengan secukup-cukupnya kerana amatlah gemar Yang Maha Mulia Sultan Turki itu melihatkan seorang raja sebelah timur begitu baik bawaan dan aturannya pada hal beragama Islam.)

Meanwhile, through the poem Syair Sultan Abu Bakar tells about the greatness of the two governments in establishing diplomatic relations;

Then the two sultans resided In front of the chief ministers Sultan Abu Bakar was a generous philanthropist The word sounds too sweet

Suddenly the caliph sat down Appointed food handlers A variety of beautiful favors Too delicious to the tongue Banquet utensils are real given Gold and silver with jewels Nothing can be say

They are all beautiful

(Lalu semayam keduanya sultan

Di hadap menteri hulubalang sekalian

Sultan Abu Bakar arif dermawan

Terlalu manis bunyi perkataan

Seketika duduk duli khalifah

Diangkat orang penganan juadah

Berbagai nikmat yang indah-indah

Terlalu lazat kepada lidah

Alat perjamuan diberi nyata)

Emas dan perak tatah permata

Tiadalah dapat hendak dikata

Sekalian itu indah semata

This royal diplomatic visit has positively affected the Johor government, especially in terms of its 
administration and diplomatic relations. Among the effects is the granting or awarding from Turkey to Johore. Sultan Abu Bakar was awarded the Uthmanli First Degree star by Sultan Abdul Hamid II during his diplomatic visit to Turkey. His escort named Haji Kassim was awarded the Majidi star. This award is important to Johor to further and strengthen the administration of Johore. It was like an early victory for Johore in stepping up the current of modernization compared to other governments' admistration around it. This event has been recorded in the Syair Sultan Abu Bakar which reads:

Abdul Hamid is the name of Sultan

Wise yet generous

Uthmanli star is his rank

The sign of friendship is already known

Haji Kassim is a martyr

Go with his Majesty

$\mathrm{He}$ is well understood and wise

Be an officer

He get one star

Majidi star it's name

the sultan's gift to him

Too much love in the heart

(Abdul Hamid namanya sultan

Arif laksana lagi dermawan

Bintang Uthmanli namanya tuan

Tanda bersahabat sudah ketahuan

Haji Kassim orang yang syahda

Pergi mengiring duli baginda

Orangnya mengerti bijak pun ada

Jadi pegawai seripada

\section{Beroleh ia bintang nan Satu}

Bintang Majidi namanya itu

Kurnia Sultan padanya itu

Terlalu suka di dalam kalbu.)

The diplomatic visit has greatly changed the Johor administration pattern, and relations between
Turkey and Johor are getting closer. According to Buyong Adil (1980), Sultan Abu Bakar has tried to set up various departments to further smooth the Johor goverment's administration equals to developed countries under the rule of the Ottoman Caliphate. This can be seen in the presence of the Office of the Government Secretary, Treasury Department, Audit Office, High Court, Government Printing Office, Career Department, Police, Survey Office, Land Office, Education Office and others. The state administration was carried out according to the Sultan and the State Assembly's intructions and assisted by several Europeans.

\section{Messenger Delivery}

The Government of Aceh is also one of the archipelago's government that has good relations with the Turkish Ottoman. Hikayat Aceh and Bustan al-Salatin are the manuscripts recorded on the relations between the two kingdoms. M.L Dames (1921) says that the history of relations between Aceh and Ottoman has built during Sultan Alauddin Shah Mahmud al-Kahhar (15371571). He applied for help to against the Portuguese colonialism. At that time, the Ottoman Turkish government took control the Red Sea waters and attacked the Portuguese fort on Diu Island, India.

Besides Hikayat Aceh and Bustan al-Salatin, there are two manuscripts about the Friday sermon, a Leiden University Library collection titled mawlana al-Sultan ibn al-Sultan 'Abd al-Aziz Khan ibn al-Marhum Mahmud Kan ibn alMarhum 'Abd al-Hamid Khan numbered Cod. Or. 229 and Jakarta National Library entitled Mawlana al-Sultan ibn al-Sultan ibn al-Sultan 'Abd al-Hamid Khan ibn al-Sultan 'Abd al-Majid Khan ibn Mahmud ibn 'Abd al-Hamid Khan numbered ML 465. Sermon manuscript written around the end of the 19th century mention the two names of Ottoman Turkish rulers, Sultan Abdul Aziz (1830-1876) in the first manuscript. And while Sultan Abdul Hamid II (1842-1918) in the second manuscript with explicitly referred to 
as Sultan to be prayed for to get the protection of Allah to win Islam. This proves that there is a special relationship between Turkey and Aceh.

Sending a messenger as a mediator has become commonplace in managing a relationship between governments. According to Muhammad, D. S. J. N. (2020), a diplomatic representative is a moderator to a government. The appointment of this post is made based on of their credibility in all aspect. Meanwhile, in Bustan al-Salatin, Chapter II, the sending of a messenger leads to a consensus relationship.

After that, the government of Sultan Alau'ddin Ri'ayat Shah ibn Sultan Mughayat Ali Shah, on Monday morning 20 months Dzulkaedah did the customs of Aceh Darussalam government and asked the messenger of the sultan of Rum, to land in Istanbul because of affirming religion.

(Kemudian daripada itu maka kerajaan Sultan Alau'ddin Ri'ayat Syah ibn Sultan Ali Mughayat Syah, pada hari Isnin waktu dhuha 20 bulan Dzulkaedah ialah yang mengadatkan segala istiadat kerajaan Aceh Darussalam dan menyuruh utusan kepada sultan Rum, ke negeri Istanbul karena meneguhkan agama Islam. )

It has become commonplace when the envoy returns to the government to be entrusted with various gifts. Turkey is known for its defence systems and modern defence and becomes a role model for other Islamic governments. Thus, it is not an impossibility when Turkey gave weapons, a skilled representative in the military field to share and show how to handle weapons. Bustan al-Salatin, the works of Nuruddin al-Raniri mentions that the delegation of the government of Acheh has brought a gift for the Acheh government upon his return from Turkey.

So the Roman's Sultan was sent to all kinds of envoys. And a wise people who knew how to use a gun. So at that time, people used huge cannons. And is the first to build a central in Acheh Darussalam, and is the first ghazis with the infidels until leaving himself attacked Malacca.

Maka dikirim sultan Rum daripada segala jenisjenis utusan dan pandai yang tahu menuang bedil. Maka pada zaman itulah dituang orang meriam yang besar-besar. Dan ialah yang pertama berbuat kota di negeri-negeri Aceh Darussalam, dan ialah yang pertama-tama ghazi dengan segala kafir sehingga sendirinya berangkat menyerang Malaka.

The above fragment continues and relates to Saim Kayzadibi (2011) statement who stated that Nuruddin al-Raniri had narrated through Bustan al-Salatin that Sultan Alaudin Riayat Syah alQahhar had sent Hussein Effendi as his ambassador to Istanbul. During the voyage, the Portuguese tried to intercept the ambassador's ship but were unsuccessful, then news of the Portuguese interference in the voyage was report to the Ottoman Caliph. Caliph sent military aid to Acheh to fight the enemy. In these missions, Acheh's ships waved the Ottoman Empire's flag in their military mission to show the two goverments' relation is beyond the boundaries of geography, but bound by the union of one.

Shipping diplomatic envoys are giving a great benefit to Acheh. Aceh became a powerful Islamic state besides the government and its high morale. By Reni Juliani (2017), Acheh was known for its tough and brave fighters. Besides being known as a thick Islamic country, Acheh also rich in spices and the spotlight of the occupiers who want to seize Acheh. However, the invaders never managed to conquer Acheh. With all their strength, Acehnese fight to expel the invaders until they successfully defended Aceh.

In Hikayat Aceh, there were events about messenger delivery. Interestingly this event is inserted with the need to cure disease. Generally must know Hikayat Aceh was written to elevate Sultan Iskandar Muda Mahkota Alam's rank, the supreme ruler of Acheh government. Sultan Iskandar Muda Mahkota Alam is the greatest and most well known, both in the East and West (Ahmad Jelani Halimi, 2008). The purpose to elevate the rank of this government is one of the features in the writing of historical literature.

This fragment began when Sultan Muhammad, the Turkish ruler, fell ill. Teuku Iskandar in his study 
of the Hikayat Aceh said, Turkey was actually ruled by Sultan Ahmad I (1603-1617) replaced Sultan Muhammad III (1594-1603). His opinion is based on the date this story was written during the reign of Sultan Iskandar Muda Mahkota Alam (1607-1636).

Sultan Muhammad had sent his envoy to Acheh, named Celebi Ahmad and Celebi Ridwan for lime oil and kerosene, which are recommended by his judges named Taimunus and Jalus. Lime is a white and fragrant material produced from the trees that usually grow in the Sumatra Islands's forest. The material is also known as camphor. In the Barus area, Sumatra, are overgrown with lime trees (Hamka, 1984). Logically, this matter can be attributed to the government of Acheh who are rich in herbal plants.

During the delegation arrived in Acheh, Sultan Iskandar Muda was at war. Therefore, the envoy had to wait for Sultan Iskandar Muda's return. After successfully defeating the Deli government, Sultan Iskandar Muda ordered to prepare to celebrate the envoys. At the same time, he went to Medan Khayyali to welcome the envoy and complete the Turkish request envoy and delegation. After that, the Turkish envoy left after they managed to get the goods requested. One thing that is pulling out of the event is the return of edthe delegation to Turkey is lifting the Acheh government administration in Sultan Muhammad eyes.

And there are conditioning the state Aceh Dar asSalam was no simple matter very cold, and there was very warm, and the horizon of the sun from the East to the dusk it coincided with the state. That is why all land contents are from humans and elephants. And from all the animals in the land are strong and brave and hard-hearted; from the human beings of the state made Allah Taala strong in his speech and many in his words and many tricks in tying the war when facing the enemy. So the kings who have passed the time of the kingdom from the grandmother of datu Seri Sultan Perkasa 'Alam have no maintenance on the city of the state, except the City of
Constellation input only a place to deliver large rifles and all large weapons.

(Dan ada hawa negeri Aceh Dar as-Salam itu sederhana jua tiada amat sejuk dan tiada amat hangat, daripada lalu cakrawala matahari dari masyrik ke maghrib itu berbetulan dengan bumi negeri itu. Maka dari kerana itulah segala isi negeri itu daripada manusyia dan gajah dan daripada segala binatang yang dalam negeri itu gagah dan berani dan tegar hati; daripada manusyia isi negeri itu dijadikan Allah Taala kuat bicaranya dan banyak bicaranya dan banyak muslihatnya pada mengikat perang tatkala berhadapan dengan seteru. Maka rajaraja yang telah lalu pada masanya kerajaan daripada nini datu Seri Sultan Perkasa 'Alam tiada kelenggara akan kota negeri itu, melainkan Kota Buruj ninpun hanya tempat mengantarkan bedil yang besar-besar dan segala senjata yang besar-besar. )

Positive statements about the Turkish delegation that has attracted the attention of Sultan Muhammad so much that he said that:

... one fine day, thanks to God's will, there were two great kings in the world of the Prophet Solomon and King Iskandar. Now in our time, there is also the blessing of God gave two great kings of the world. To the west we are the great king and to the east Sri Sultan Perkasa Alam [Iskandar Muda] is the great king and upholds Allah and His Prophet's religion.

...pada waktu yang sudah-sudah berkat kehendak Tuhan ada dua raja besar di dunia Nabi Allah Sulaiman dan Raja Iskandar. Sekarang pada zaman kita juga ada berkat kehendak Tuhan dua raja besar di dunia. Di barat kamilah raja besar itu dan di timur Sri Sultan Perkasa Alam [Iskandar Muda] lah raja besar itu dan yang menjunjung tinggi agama Allah dan Nabinya.

The statement is a confession of Sultan Muhammad to Sultan Iskandar Muda who was brave and famous. This is because it is not easy to get recognition from a great government that is likened to the head of the caliph to all Islamic governments in the world. Hikayat Aceh record 
this meaningful event for reading to the next generation that there is a government in the country that has gotten the the Ottoman's. One of the sources of such contributions is through the sending of messengers.

\section{Conclusion}

Undoubtedly, the Turkish Caliphate Utmaniyah strongly influence the Malay kingdom in various angles. Leiden University's Library, one of the largest institution that keeping and collecting the science literature and historical records of the Malay sultanates in the archipelago and keeps the most important manuscripts that told the relationships between Turkey and Malaya. Thus, a comprehensive and continuous study towards these treasures is needed, so that the stored knowledge can be disseminated to the public.

The results found from the Malay manuscript that have been used as a discussion material about the relationship between Turkey and Malaya can be attributed. Such as lineage, the royal visit that led to marriage and recognition, and the delivery of messengers that bring the positive impact towards the Malay kingdom's greatness. In this discussion, the author obtained; that Johore, Aceh and Kedah have a close relationship with Turkey. Nevertheless, the author also aware that several major influences have not been discussed in this writing and also there are other kingdoms in this archipelago involved. Therefore, further research and in-depth research need to be done to highlight Turkish Empire's influences towards Malay kingdom by relying to Malay manuscripts.

\section{References}

[1] Abd Jalil, Borham. 2011. Pengaruh Khilafah Othmaniyyah Turki Dalam Pentadbiran Kerajaan Johor Bagi Memartabatkan Sebuah Negara Islam Merdeka Di Asia Tenggara. In: Simposium Isu-Isu Sejarah dan Tamadun Islam (SISTI 2011) Peringkat Kebangsaaan, 8-10 April 2011, Universiti Kebangsaan Malaysia, Bangi.
[2] Abdullah, A. R. 2013. Hikayat Johor dan Kepentingannya sebagai Sumber Sejarah Johor Moden: 1833-1895. Perspektif: Jurnal Sains Sosial Dan Kemanusiaan, 5(2), 29 - 43. Retrieved from

https://ejournal.upsi.edu.my/index.php/PE RS/article/view/1635.

[3] Ahmad Jelani Halimi. 2008. Sejarah dan Tamadun Bangsa Melayu. Kuala Lumpur: Utusan Publications \& Distributors.

[4] Anthony C. Milner. 2004. Afterword: A History of Malay Ethnicity dalam Timothy P. Barnard (sunt.) Contesting Malayness Malay Identity Across Boundaries. Singapore : National University Press.

[5] Anthony H. John. 1982. The Turning Image: Myth and Reality in Malay Perceptions of the Past, dalam Anthony Reid \& David Marr (eds), Perceptions of the Past in Southeast Asia. Singapore : Heinemann Educational Books.

[6] Buyong Adil. 1980. Sejarah Johor. Kuala Lumpur: Dewan Bahasa dan Pustaka.

[7] Dzulkifli Salleh. 1965. Hikayat Merong Mahawangsa. Kuala Lumpur: Dewan Bahasa dan Pustaka.

[8] Hamka. 1984. Tafsir al-azhar. Surabaya: Yayasan Latimojong.

[9] Harun Mat Piah Ismail Hamid, Siti Hawa Salleh, Abu Hassan Sham, Abdul Rahman Kaeh and Jamilah Haji Ahmad. 2000. Kesusasteraan Melayu Tradisional. Kuala Lumpur: Dewan Bahasa dan Pustaka.

[10] Hendrik M.J. Maier. 1988. In the Center of Authority: The Malay Hikayat Merong Mahawangsa. Ithaca, NY: Southeast Asia Program, Cornell University.

[11] Mat Rofa Ismail. 2015. Kerdipan Bintang Melayu Di Langit Turki. Shah Alam: Grup Buku Karangkraf.

[12] Milner, A., \& Abdullah, A. 2014. Hikayat Johor dan Tawarikh Almarhum Sultan Abu Bakar: Kajian, Transliterasi dan Terjemahan by Abdullah A. Rahman 
Tang. Journal of the Malaysian Branch of the Royal Asiatic Society, 87(2 (307)), 99101. doi:10.2307/26527677

[13] M.L.Dames. 1921. The Portuguse and Turks in the Indian Ocean in the Sixteenth Century. Journal of the Royal Asiatic Society. Vol 1: 16-19.

[14] Mohammad Isa Othman. 1990. Politik Tradisional Kedah 1681-1942. Kuala Lumpur: Dewan Bahasa dan Pustaka.

[15] Mohd Yusof Md Nor. 2000. Syair Sultan Abu Bakar: Dokumentasi Sejarah Negeri Johor. Dewan Sastera. Vol. 30 (7):12-16.

[16] Mohd. Said Sulaiman. 1930. Hikayat Johor. Johor: Johor Government Publishing Office.

[17] Muhammad, S. J. N. (2020). Diplomatic Negotiation For Representative In Conflict Resolution. International Journal of Advanced Science and Technology, 29(4s), 472 - 476.

[18] Musa, H., Rodi, R.C., Pondo, H., Muhammad, S.J.N. (2013.) Malay language and the concept of true knowledge from the perspective of Syed Muhammad Naquib al- Kemanusiaan, 20(1,): 1-22.

[19] Nurul Izzah Mohd Johari, Tajul Shuhaizam Said \& Harozila Ramli. 2020. Kesinambungan Warisan Kesenian Langkasuka di Tanah Melayu. International Journal of the Malay World and Civilisation, 8(2), 2020: 51 - 62

[20] Reni Juliani. 2018. Menarik Benang Merah Hubungan Aceh Dengan Sulawesi Selatan. SOURCE: Jurnal Ilmu Komunikasi. Vol 3 (1): 1-15.

[21] Rozali, E. A. (2015). Aceh-Ottoman Relation in Bustan alSalatin. Mediterranean Journal of Social Sciences, 5(29), 93. Retrieved from http://www.richtmann.org/journal/index.ph p/mjss/article/view/5427

[22] Saim Kayzadibi. 2011. Ottoman Connections to the Malay World: Islam,
Law and Society. Kuala Lumpur: The Other Press.

[23] Salmah Jan Noor Muhammad. 2017. Kerencatan Hubungan Diplomatik Kesultanan Melayu Melaka, Johor dan Aceh (The Deterrence of Malay Government Diplomatic Relationship with Malacca, Johore and Aceh). MANU. Bil. 25: 107-136.

[24] Siti Hawa Salleh, $1998 . \quad$ Hikayat Merong Mahawangsa. Kuala Lumpur: Yayasan Karyawan dan Penerbitan Universiti Malaya.

[25] Teuku Iskandar. 1995. Kesusasteraan Klasik Melayu Sepanjang Abad. Brunei: Universiti Brunei Darussalam. 